\section{High Pressures in Non-Invasive Ventilation in Children, Where is the Limit?}

\section{Abstract}

Non-invasive positive pressure ventilation (NPPV) refers to the delivery of mechanical respiratory support without the use of endotraqueal intubation. It has been proposed as a valuable alternative to invasive mechanical ventilation (MV) in selected children with acute respiratory failure (ARF). The pressures usually employed in NPPV are lower than those in MV, but in some cases high pressures are needed.

We present two patients that needed NPPV.

Keywords: Non-invasive ventilation; Acute respiratory failure; Postoperative respiratory failure

Received: December 03 2015; Accepted: February 15, 2016; Published: February 22, 2016

\section{First Case}

9 year old girl who arrived at our hospital with acute respiratory distress. She presented with a history of high-grade fever for 4 days, dry coughing and respiratory fatigue. At emergency box, she was markedly polypneic (Respiratory Rate (RR): 80 , Heart Rate (HR): 160 , Blood Pressure: $120 / 60$, Temperature: $39.5^{\circ} \mathrm{C}$ ) and fatigued, but alert and reactive. Diffuse subcrepitant rales were presented and chest radiograph showed diffuse alveolar infiltration in both lungs.

It was decided to be admitted in Pediatric Intensive Care Unit for respiratory support. NPPV was started on this girl. We use BiPAP Vision Respironics ${ }^{\odot}$ and facial mask as interface. Initial parameters were; inspiratory positive airway pressure (IPAP): $22 \mathrm{~cm} \mathrm{H}_{2} \mathrm{O}$, expiratory positive airway pressure (EPAP): $7 \mathrm{~cm} \mathrm{H}_{2} \mathrm{O}$ and fraction of inspired oxygen $\left(\mathrm{FiO}_{2}\right): 1$. We did not observed improvement in the first hour, so intubation was required. $\left(\mathrm{PaO}_{2} / \mathrm{FiO}_{2}: 110\right.$, in the first hour decreased to 80$)$.

After 6 days, she was extubated to NPPV. She needed high pressures (IPAP: $32 \mathrm{~cm} \mathrm{H}_{2} \mathrm{O}$, EPAP: $8 \mathrm{~cm} \mathrm{H}_{2} \mathrm{O}, \mathrm{FiO}_{2}: 0,3$ ) during the first 48 hours with good evolution, and without any complications.

\section{Second Case}

10 year old boy admitted in our Pediatric Intensive Care Unit after abdominal surgery (complicated peritonitis that needed resection of part of the colon). He was extubated in the first 24 hours to high flow nasal cannula, but the following day he

\section{Bejarano Ramirez $\mathbf{N}^{1}$, Redondo Calvo FJ', Raya Perez I ${ }^{1}$ and Garcia Cabezas MA ${ }^{1}$}

\section{Department of Pediatrics, Pediatric Critical Care Unit, Hospital General Universitario de Ciudad Real, Spain \\ 2 Department of Anesthesiology and Critical Care Medicine, Hospital General Universitario de Ciudad Real, Ciudad Real, Spain}

\section{Corresponding author: \\ Bejarano Ramirez N}

\section{”nbejarano@sescam.jccm.es}

Hospital General Universitario De Ciudad Real. C/Obispo Rafael Torija S/N 13005, Ciudad Real, Spain,

Citation: Bejarano Ramirez N, Redondo Calvo FJ, Raya Perez I, et al. High Pressures in Non-Invasive Ventilation in Children, Where is the Limit? J Intensive \& Crit Care 2016, 2:1.

presented respiratory failure with hipoxemia. Radiograph chest showed complete atelectasis of right lung, so NPPV was started. The ventilator used was BiPAP Vision Respironics ${ }^{\circledR}$ and full-face mask. He needed high pressures to achieve acceptable ventilation (IPAP: $30 \mathrm{~cm} \mathrm{H}_{2} \mathrm{O}$, EPAP: $10 \mathrm{~cm} \mathrm{H}_{2} \mathrm{O}, \mathrm{FiO}_{2}$ : 1). NPPV was kept during 48 hours and it was well tolerated (Table 1 ).

\section{Conclusion}

The frequency of ARF is higher in infants and young children than in adults. This difference can be explained by defining anatomic compartments and their developmental differences in pediatric patients that influence susceptibility to $\operatorname{ARF}[1,2]$.

The main goals of NPPV in patients with parenchymal lung disease are to improve oxygenation, to unload the respiratory muscles and to relieve dyspnea. The first goal can be achieved by using EPAP to recruit and stabilize previously collapsed lung tissue. IPAP allows a better respiratory system muscle unloading and $\mathrm{CO}_{2}$ washout improvement [3]. 
In children, the use of NPPV for the treatment of acute respiratory distress syndrome (ARDS) was associated with a failure rate of $78 \%$, that's why if the patient conditions deteriorated, he should be promptly intubated, as in our first case.

It has been reported that $5-10 \%$ of all surgical adult patients experience postoperative pulmonary complications, like atelectasis, postoperative pneumonia or ARDS. Several authors report that NPPV compared with standard treatment after major abdominal surgery improved hypoxemia and reduced the need of intubation in adult population. NPPV application in children with postoperative respiratory failure was associated with improved respiratory effort, gas exchange, oxygen saturation and reduced need of intubation [2, 4-6]. It is also reported that exit of NPPV in atelectasis after extubation is near $100 \%$ like in the second patient we referred.

Some authors have referred that postextubation NPPV seems to be useful in avoiding reintubation in high-risk children when applied immediately after extubation. NPPV was more likely to fail when ARF has already developed, when RR at 6 hours did not decrease and if oxygen requirements increased [7-9].
In some patients with ARF, high pressures are needed to get good ventilation. Several authors described maximum values (IPAP $20 \mathrm{~cm} \mathrm{H}_{2}$, EPAP $10 \mathrm{~cm} \mathrm{H}_{2}$ ) in their studies. They referred that higher pressures are not well tolerated by their patients or might cause complications, being the most frequent, skin injury and discomfort $[7,10]$. In our cases, the patients needed high pressures in order to get good ventilation, and they didn't showed any complications, so we thought that the limit should be established depending on the patient, the cause of ARF and the experience of the personal who attends these patients.

Increased intrathoracic pressure may limit diastolic filling by several mechanisms. These include increased external constraint to the heart, redistribution of blood from the thorax to the periphery, and direct ventricular interaction. The effects of high pressures in non-invasive ventilation in children on left ventricular preload are closely related to mean airway and filling pressures and not to the mode of ventilation. The left ventricular preload similarly decreases with increased airway pressure and consequently cardiac output $[11,12]$. In this context the echocardiography, color-flow Doppler and tissue Doppler imaging may provide further important information about cardiac function [13, 14].

Table 1 Shows ventilation timings for treatment of patients.

\begin{tabular}{|c|c|c|c|c|c|c|c|c|}
\hline & 0 hour & 1 hour & 168 hours & 176 hours & O hour & 24 hours & 36 hours & $42 \mathrm{~h}$ \\
\hline $\mathrm{RR}$ & 80 & 70 & 45 & 35 & 30 & 2 & 60 & 50 \\
\hline HR & 160 & 150 & 105 & 100 & 130 & 110 & 140 & 125 \\
\hline $\mathrm{BP}$ & $120 / 60$ & $120 / 65$ & $120 / 60$ & $115 / 60$ & 115 / 55 & $120 / 65$ & $120 / 66$ & $115 / 60$ \\
\hline Sat $\mathrm{O}_{2}$ & $85 \%$ & $85 \%$ & $95 \%$ & $96 \%$ & $96 \%$ & $98 \%$ & $87 \%$ & $93 \%$ \\
\hline $\mathrm{PaO}_{2} / \mathrm{FiO}_{2}$ & 110 & 80 & 270 & 280 & $>300$ & $>300$ & 150 & 210 \\
\hline \multirow[t]{2}{*}{ Treatment } & NPPV & MV & NPPV & NPPV & MV & Extubation & NPPV & NPPV \\
\hline & $\begin{array}{c}\text { S / T } \\
\text { IPAP:22 } \\
\text { EPAP: } 7 \\
\mathrm{FiO}_{2}: 1\end{array}$ & & $\begin{array}{c}\mathrm{S} / \mathrm{T} \\
\text { IPAP:32 } \\
\text { EPAP:8 } \\
\mathrm{FiO}_{2}: 0,3\end{array}$ & $\begin{array}{c}\text { S / T } \\
\text { IPAP:28 } \\
\text { EPAP: } 7\end{array}$ & & $\begin{array}{l}\text { High Flow nasal } \\
\text { canula }\end{array}$ & $\begin{array}{c}\text { S / T } \\
\text { IPAP: } 30 \\
\text { EPAP:10 } \\
\text { FiO }_{2}: 1\end{array}$ & $\begin{array}{c}\mathrm{S} / \mathrm{T} \\
\text { IPAP: } 27 \\
\text { EPAP:8 } \\
\mathrm{FIO}_{2}: 0,4\end{array}$ \\
\hline Sedation & $M+F$ & & & & $M+F$ & & & \\
\hline
\end{tabular}

First case

Second case

RR: Respiratory Rate (rpm); HR: Heart Rate; BP: Blood Pressure; M: Midazolam; F: Fentanyl; NPPV: Non Invasive Positive Pressure Ventilation; S / T: Spontaneous-Timed; IPAP: Inspiratory Positive Airway Pressure $\left(\mathrm{cm} \mathrm{H}_{2} \mathrm{O}\right)$; EPAP: Expiratory Positive Airway Pressure $\left(\mathrm{cm} \mathrm{H}_{2} \mathrm{O}\right)$. 


\section{References}

1 Rota AT, Wiryawan B (2003) Respiratory emergencies in children. Respir Care 48: 248-258.

2 Stucki P, Perez MH, Scalfaro P, de Halleux Q, Vermeulen F, et al. (2009) Feasibility of non-invasive pressure support ventilation in infants with respiratory failure after extubation: a pilot study. Intensive Care Med 35: 1623-1627.

3 Yanez LJ, Yunge $M$, Emilfork $M$, Lapadula $M$, Alcántara $A$, et al. (2008) A prospective, randomized, controlled trial of non-invasive ventilation in pediatric acute respiratory failure. Pediatr Crit Care Med 9: 484-489.

4 Bernet V, Hug Mi, Frey B (2002) Predictive factors for the success of non-invasive mask ventilation in infants and children with acute respiratory failure. Pediatr Crit Care Med 6: 660-664.

5 Joshi G, Tobias JD (2007) A five year experience with the use of the BiPAP in a pediatric intensive care unit population. J Intensive Care Med 22: 38-43.

6 Essouri S, Chevret L, Durand P, Haas V, et al. (2006) Non-invasive positive pressure ventilation: five years of experience in a pediatric intensive care unit. Pediatr Crit Care Med 7: 329-334.

7 Mayordomo-Colunga J, Medina A, Rey C, Concha A, Menéndez S et al. (2010) Non-invasive ventilation after extubation in paediatric patients: a preliminary study. BMC Pediatr 10: 29.
8 Munoz-Bonet JI, Flor-Macian EM, Brines J, Rosello-Millet PM, Cruz Llopis M, et al. (2010) Predictive factors for the outcome of noninvasive ventilation in pediatric acute respiratory failure. Pediatr Crit Care 11: 675-680.

9 Abadesso C, Nunes P, Silvestre C, Matias E, Helena Loureiro et al. (2012) Non-invasive ventilation in acute respiratory failure in children. Pediatr Resp 4: e16.

10 Pons Odena M, Piqueras Marimbasa I, Segura Matute $S$, Balaguer Argallo M, Palomeque Rico A (2009) Aplicación de ventilación no invasiva en pacientes postoperados cardiacos. An Pediatr 71: 13-19.

11 Jardin F, Farcot JC, Boisante L, Margairaz A, et al. (1981) Influence of positive end-expiratory pressure on left ventricular perfomance. $\mathrm{N}$ England J Med 3014: 387-392.

12 Arnold JH, Hanson JH, Toro-Figuero LO, Gutiérrez J, Berens RJ, et al. (1994) Prospective, randomized comparison of high-frequency oscillatory ventilation and conventional mechanical ventilation in pediatric respiratory failure. Critical Care Medicine 22: 1530-1539.

13 Ciccone MM, Scicchitano P, Zito A, Gesualdo M, Sassara M, et al. (2011) Different functional cardiac characteristics observed in term/ preterm neonates by echocardiography and tissue doppler imaging. Early Hum Dev 87: 555-558.

14 Brunetti L, Francavilla R, Scicchitano P, Tranchino V, Loscialpo M, et al. (2013) Impact of sleep respiratory disorders on endothelial function in children. Scientific World Journal 2213: 719456. 